Radostaw Kiejstut Kardaś

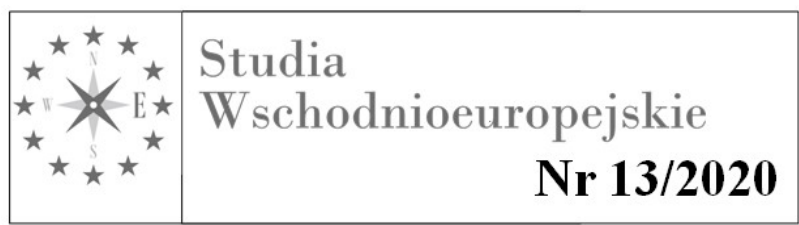

\title{
Procesy demograficzne w Tadżykistanie ${ }^{344}$
}

adżykistan jest jedną $\mathrm{z}$ najbiedniejszych republik byłego $\mathrm{ZSRR}^{345}$ o znaczącym
potencjale demograficznym. W 2018 roku przyrost naturalny republiki kształtował się na poziomie $22,0 \%, 71 \%$ populacji stanowiły osoby do 34 roku życia ${ }^{346}$, natomiast zasoby pracy wyniosły blisko $60 \%{ }^{347}$. Prognozy ONZ wskazują, że w 2050 r. liczba mieszkańców tego państwa $\mathrm{z}$ obecnych $9,4 \mathrm{mln}$ może wzrosnąć do $14,5 \mathrm{mln}^{348}$. Z uwagi na słabo rozwiniętą gospodarkę $^{349}$ oraz sytuację na runku pracy ${ }^{350}$ Tadżykistan nie może w pełni wykorzystać swojego potencjału demograficznego. Pomimo, iż średni wzrost PKB w latach 2007 - 2017 był na poziomie $6,8 \%$, to nie udało się stworzyć odpowiedniej liczby miejsc pracy dla przybywających w szybkim tempie nowych pracowników ${ }^{351}$. Skutkiem tego jest wzmożona

\footnotetext{
${ }^{344}$ Prace na artykułem zostały zakończone w czerwcu $2020 \mathrm{r}$.

345 PKB per capita w 2018 r. w Tadżykistanie wyniosło 826,6 UDS. Dla porównania w Kirgistanie (1281,4 UDS), Uzbekistanie (1532,4 UDS), Turkmenistanie (6966,6 UDS), Kazachstanie (9812,6 UDS). Dane za: GDP per capita (current US\$) - Tajikistan, Uzbekistan, Kyrgyz Republic, Turkmenistan, Kazakhstan, World Bank Data, 2018, za: https://data.worldbank.org/indicator/NY.GDP.PCAP.CD?locations=TJ-UZ-KG-TM-KZ (10.04.2020).

346 Należy wskazać, że z tak szybkim przyrostem naturalnym wiążą się problemy związane m.in. $\mathrm{z}$ niewydolnością systemu opieki społecznej i medycznej. Z danych za 2018 r. wynika, iż w Tadżykistanie jest 490 szpitali, 1711 placówek medycznych, na 10000 osób przypada 20,9 lekarzy i 59,2 osoby personelu medycznego. Zob. Основные показатели развития здравоохранения, 1991-2018, Агентство по статистике при Президенте Республики Таджикистан.

347 Zob. Основные демографические показатели, 1991-2018, Агентство по статистике при Президенте Республики Таджикистан.

${ }^{348}$ Zob. World Population Prospects, 2017 Revison. Volume I: Comprehensive Tables, Department of Economic and Social Affairs Population Division, United Nations, New York 2017, s. 21.

${ }^{349}$ Głównymi gałęziami gospodarki są rolnictwo, przemysł i handel, które w 2019 r. stanowiły w strukturze PKB Tadżykistanu odpowiednio 19,8\%, 17,4\% i 15,1\%. Zob. Краткая информация о текущей ситуации 8 экономике Республики Таджикистанза 2019 год. https://www.medt.tj/ru/makroekpnpmika/sostoyanie/1203nati-a-oi-rushdi-i-timoiyu-i-tisodii-um-urii-to-ikiston-dar-nimsoli-yakumi-soli-2019 (10.04.2020).

${ }^{350}$ Według danych Międzynarodowej Organizacji Pracy stopa bezrobocia w 2019 r. wyniosła 11,02\%. Zob. Unemployment, total (\% of total labor force) (modeled ILO estimate) - Tajikistan, https://data.worldbank.org/indicator/SL.UEM.TOTL.ZS?locations=TJ (28.03.2020). Szczególnie trudna jest sytuacja ludzi młodych (15-24). Stopa bezrobocia w tej kategorii osób w 2019 r. wyniosła 20,57\%. Zob. Tajikistan: Youth unemployment rate from 1999 to 2019,https://www.statista.com/statistics/813092/youthunemployment-rate-in-tajikistan/ (10.04.2020).

${ }^{351}$ W latach 2007 - 2017 roczny wzrost liczby miejsc pracy był na poziomie 1,1\% (23 364), podczas gdy populacja $\mathrm{w}$ wieku produkcyjnym wzrosła o ok. 3\% (łącznie 1,3 miliona osób). Zob. Tajikistan. Country
} 
migracja ludności, która $\mathrm{w}$ ostatnich latach nabrała charakteru masowego, a transfery pieniężne migrantów ratują budżet państwa i gospodarstw domowych ${ }^{352}$.

Autor zdecydował się na podjęcie tematu procesów demograficznych w Tadżykistanie z nadzieją na wypełnienie luki w badaniach w tym obszarze ${ }^{353}$. Wpływ na wybór tematyki miały także obserwacje poczynione $\mathrm{w}$ trakcie udziału w realizacji projektu pt. „Tajikistan III w ramach Inicjatywy MIEUX ${ }^{, 354}$ prowadzonego przez International Centre for Migration Policy Development w latach 2017 - 2019. W opracowaniu podjął próbę opisu ważniejszych czynników rzutujących na procesy demograficzne w niepodległym Tadżykistanie. Swoje rozważania rozpoczyna od charakterystyki ważniejszych wskaźników demografii Tadżyckiej SRR, a następnie diagnozuje tendencje i specyfikę zmian w populacji już niepodległego Tadżykistanu.

\section{Demografia w Tadżyckiej SRR}

W 1925 r. w Tadżyckiej Autonomicznej Socjalistycznej Republice Radzieckiej (powstałej w 1924 r. w składzie Uzbeckiej SRR) ${ }^{355}$ zamieszkiwało 990 tys. 900 osób, natomiast w 1959 r. było to już $1 \mathrm{mln} 979$ tys. ludności. W ciągu 34 lat populacja republiki wzrosła blisko dwukrotnie. Dynamiczny wzrost ludności można było zaobserwować w kolejnych dekadach. W 1970 r. republika liczyła 2 mln 899 tys. osób (wzrost na poziomie

Economic Memorandum. Nurturing Tajikistan's Growth Potential. Macroeconomics, Trade and Investment Global Practice, Europe and Central Asia Region. Washington 2019. s. xiv i xv.

${ }^{352}$ Według danych Centralnego Bank Rosji w I kwartale 2019 r. suma środków przekazanych przez migrantów pracujących w Rosji wyniosła 111,792 mln UDS. Należy jednak mieć na uwadze, że największa suma przekazów pieniężnych przypada na II i III kwartał. Jest to wynikiem charakteru migracji Tadżyków, która jest przede wszystkim sezonowa. Warto odnotować, że dysproporcja jaka miała miejsce jeszcze parę lat temu pomiędzy poszczególnymi kwartałami w przypadku wielkości przekazów pieniężnych nie jest już tak duża. Dla przykładu w 2018 r. wielkość przekazów w podziale na kwartały wynosiła: I kw. - 157,673 mln USD, II kw. 240,561 mln UDS, III kw. - 253,758 mln USD, IV kw. - 182,60 mln USD. Natomiast w 2014 r.: I kw. - 644,00 mln USD, II kw. - 1024,41 mln USD, III kw. - 1348,00 USD, IV kw. - 814,38 mln USD. Zоb. Переводы из России, осуществленные через системы денежных переводовс I квартала 2014 г. по IV квартал 2018 г., za: http://www.cbr.ru/statistics/macro_itm/tg/ (10.04.2020). W 2017 r. środki przekazane przez migrantów stanowiły aż 38\% PKB. Zob. Таджикистан: Экономический меморандум по стране 2019, za: https://www.vsemirnyjbank.org/ru/news/infographic/2019/08/30/tajikistan-cem-2019 (10.04.2020).

${ }^{353}$ Jedynym naukowym opracowaniem w języku polskim poświęconym demografii Tadżykistanu jest rozdział pt. Procesy demograficzne napisany przez Tadeusza Bodio, Sadułło Isłomowa, Witolda Śmidowskiego, w książce pt. T. Bodio (red.), Tadżykistan, Historia, społeczeństwo, polityka, Warszawa, 2002.

${ }^{354}$ MIEUX (MIgration EU eXpertise) to narzędzie działające na zasadzie peer-to-peer, które wspiera kraje partnerskie i organizacje regionalne w lepszym zarządzaniu migracją i mobilnością poprzez zapewnianie szybkiej, dostosowanej do potrzeb pomocy. Od 2009 r. ponad 100 krajów skorzystało z działań MIEUX na rzecz budowania zdolności migracyjnych. MIEUX jest finansowana przez Unię Europejską.

35516 października 1929 r. III Nadzwyczajny Zjazd Rad ZSSR zatwierdził Deklarację ws. Przemianowania Tadżyckiej Autonomicznej Socjalistycznej Republiki Radzieckiej w Tadżycką Socjalistyczną Republikę Radziecką. 
przekraczającym 107\% na przestrzeni zaledwie 11 lat), w 1979 r. - prawie 3 mln 806 tys. (wzrost o ponad 31\% w ciągu 10 lat), a w 1989 r. ponad 5 mln 90 tys. (wzrost ok. 34 \%) ${ }^{356}$.

Interesująco przedstawiał się udział ludności wiejskiej i miejskiej w dynamice demograficznej. Otóż dane za lata 1925 - 1989 ujawniają znaczące dysproporcje w danym zakresie. Z danych za 1925 r. wynika, że liczba ludności miejskiej wynosiła 86 tys. 300 osób, a wiejskiej 904 tys. 600 osób. Natomiast w 1989 r. odpowiednio $1 \mathrm{mln} 655$ tys. 105 i $3 \mathrm{mln}$ 437 tys. 498 osób. Od 1925 r. do 1970 r. obserwuje się zwiększający się udział populacji ludności miejskiej w całej populacji, który był efektem polityki przemysłowej w Tadżyckiej SRR. W rezultacie nastąpił rozwój miast i rozpoczął się szybko postępujący proces urbanizacyjny. Wiązał się on $\mathrm{z}$ skupieniem produkcji przemysłowej w dużych miastach, tworzeniem licznych osiedli typu miejskiego w obszarach nowego zagospodarowania i z masowym przesiedlaniem ludności ze wsi do miast ${ }^{357}$. Z urbanizacją korelował proces industrializacji, który również wiązał się z przesiedleniem ludności (m.in. inżynierów, techników), tym razem $z$ bardziej rozwiniętych części ZSRR ${ }^{358}$. Od połowy lat 70. udział procentowy ludności miejskiej w populacji republiki zaczął spadać by 1989 r. osiągnąć nieco ponad $32 \%{ }^{359}$.

Jeśli chodzi o wskaźnik liczby kobiet przypadających na 100 mężczyzn, to w danym okresie systematycznie on spadał, z poziomu 105,3 do 101,3. Biorąc natomiast pod uwagę strukturę populacji według płci, to można zauważyć, że udział kobiet przeważał, choć zarysowywała się tu tendencja spadkowa. W 1979 r. udział kobiet wynosił 50,6\% a mężczyzn 49,4\%, natomiast w 1989 r. 50,3\% kobiet do 49,6\% mężczyzn ${ }^{360}$.

\footnotetext{
${ }^{356}$ Dane za 1925 r. za: Демографический ежегодник Республики Таджикистан, Душанбе 2019, s 22. Dane z lat 1939, 1959, 1970, 1979, 1989 za: Всесоюзная перепись населения 1939 года, Всесоюзная перепись населения 1959 года, Всесоюзная перепись населения 1970 года, Всесоюзная перепись населения 1979 года, Всесоюзная перепись населения 1989 года; Natomiast Bank Światowy podaje nieco inne dane np. w 1960 r. - 2,087 mln osób, w 1970 r. - 2,930 mln osób, w 1980 r. - 3,905 mln osób a w 1989 r. - 5,149 mln osób. Zob. World Bank Data, https://data.worldbank.org/country/tajikistan (16.04.2020).

357 Zob. Урбанизация в Центральной Азии: вызовы, проблемы и перспективы. Аналитический доклад 2013/03, ЦЭИ, ЭСКАТО и ПРООН, Ташкент 2013, s. 17.

$358 \mathrm{~W}$ rezultacie $\mathrm{w}$ latach 50 . i 60 . powstał tzw. binarny system rozmieszczenia populacji. W miastach koncentrowała się głównie ludność spoza Tadżykistanu, która zajmowała kluczowe stanowiska w administracji i zarządzaniu przedsiębiorstwami. Natomiast rdzenni mieszkańcy przeważnie mieszkali na obszarach wiejskich. Zob. Урбанизачия в Центральной..., op. cit. s. 19.

${ }^{359}$ Zob. Демографический ежегодник..., ор. cit., s. 30.

${ }^{360}$ Ibidem.
} 


\section{Wykres 1. Dynamika wzrostu populacji ludności zamieszkującej w latach 1925 - 1989 na terytorium Tadżykistanu - w podziale na ludność miejską i wiejską}

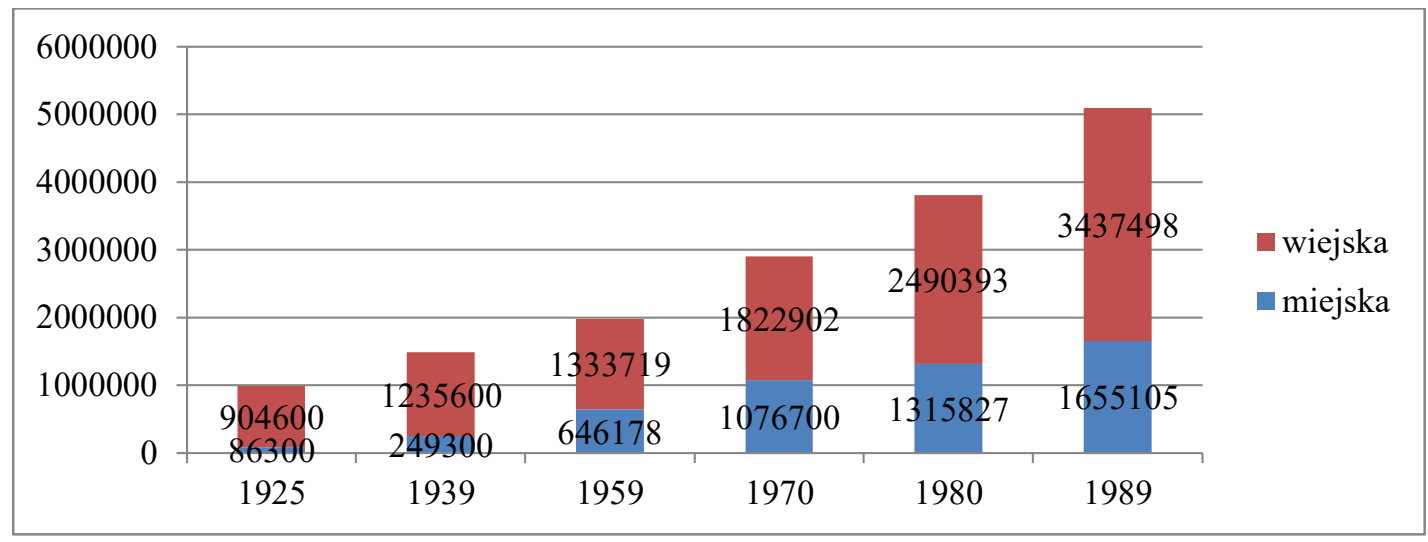

Źródło: Opracowanie własne na podstawie danych za: dane za 1925 r. za: Демографический ежегодник..., ор. cit. s. 22. Dane z lat 1939, 1959, 1970, 1979, 1989 za: Всесоюзная перепись населения 1939 года, Всесоюзная перепись населения 1959 года, Всесоюзная перепись населения 1970 года, Всесоюзная перепись населения 1979 года, Всесоюзная перепись населения 1989 года.

Wysoka dynamika przyrostu populacji Tadżyckiej SRR w pierwszych latach jej funkcjonowania wynikała przede wszystkim $\mathrm{z}$ powiększenia się jej terytorium ${ }^{361}$. W kolejnych, była związana zwysoką liczbą urodzeń dzieci (współczynnik dzietności w 1960 r. - 4,51; 1970 - 6,13; 1976 - 6,32, 1981- 5,66; 1986 - 5,61; 1990 - 5,09), wydłużającą się średnią długością życia (wzrost z 66,1 lat w 1978 do 70,5 lat w 1991 r.) oraz poprawą opieki zdrowotnej $^{362}$. W tym kontekście warto zwrócić uwagę na politykę władz radzieckich w odniesieniu do płci w tym macierzyństwa. Korelowała ona i była pod wieloma względami zgodna z wyobrażeniami i zwyczajami narodów Azji Centralnej, w szczególności Tadżyków, gdzie macierzyństwo - jak pisze S. Kasymowa - stanowiło rdzeń kategorii „kobieta”. Ciąża i poród nie były prywatną sprawą kobiety; nie mogła ona samodzielnie decydować o czasie i liczbie ciąż $\dot{z}^{363}$. Dodatkowo, elementem który również miał wpływ na wysoką liczbę urodzeń w Tadżyckiej SRR była tradycja posiadania wielodzietnej rodziny ${ }^{364}$.

T. Bodio, S. Isłomow, W. Śmidowski wskazują, że procesy demograficzne w czasach radzieckich Tadżykistanu bardzo mocno korelowały z procesami socjopolitycznymi. Na splot

\footnotetext{
${ }^{361}$ W 1929 r. do Tadżyckiej ASSR został przyłączony obwód Chodżentu (250,8 tys. mieszkańców) oraz inne terytoria (1 mln 100 tys. osób).

362 Zob. T. Bodio, S. Isłomow, W. Śmidowski, Procesy demograficzne, [w:] Tadżykistan, Historia, społeczeństwo, polityka, T. Bodio (red.), Warszawa 2002, s. 293.

363 Ponadto należy mieć na uwadze, że władze radzieckie ograniczały również prawo kobiet do aborcji, a w latach 1930 - 1950 zniosły je wogóle. Zachęcały również moralnie i materialnie do posiadania dużej rodziny. Zob. C. Касымова, Традиция многодетного материнства у таджиков в контексте гендера и времени. Вестник Евразии. №4 (34). М., 2006, s. 64 і 65.

${ }^{364}$ Prezydent Tadżykistanu Emomali Rachmon posiada 9 dzieci.
} 
tych czynników nakładały się także uwarunkowania historyczne, polityczne, kulturowe, religijne, gospodarcze i geograficzne ${ }^{365}$.

Warto zwrócić uwagę na strukturę narodowościową. Z danych spisu powszechnego z 1939 r. wynika, że republika była zamieszkiwana przez 883 tys. 966 Tadżyków, 353 tys. 478 Uzbeków, 134 tys. 916 Rosjan. Natomiast pozostałe narodowości łącznie liczyły 112 tys. 80 osób $^{366}$. W 1959 r. liczba rdzennych Tadżyków zwiększyła się do $1 \mathrm{mln} 51$ tys. 164 osób, a Uzbeków do 454 tys. 433 osób, zaś Rosjan do 262 tys. 610 osób. Populacja pozostałych narodowości wzrosła do ponad 282 tys. osób ${ }^{367}$.

Ze spisu w 1970 r. wynika, iż liczba Tadżyków wzrosła do 1 mln 629 tys. 920 osób, Uzbeków do 665 tys. 662, a Rosjan do 344 tys. 109 osób, natomiast pozostałych narodowości spadła do poziomu 259 tys. 911 osób $^{368}$. Spis z 1979 r. pokazuje, że utrzymał się trend wzrostowy populacji Tadżyków (2 mln 237 tys. 048), Uzbeków (873 tys. 199) i Rosjan (395 tys. 089). Odnotowano także wzrost liczby pozostałych grup narodowościowych do 300 tys. 884 osób $^{369}$. Ostatni spis powszechny przeprowadzony w ZSRR był w 1989 r. Zawarte w nim dane ujawniają, że w ciągu 10 lat nastąpił bardzo duży wzrost liczby Tadżyków - 3 mln 172 tys. 420. Liczba Uzbeków i przedstawicieli ponad 100 innych narodowości i grup etnicznych również uległa zwiększeniu osiągając odpowiedniol mln 197 tys. 841 i 333 tys. 861 osób. Odnotowano natomiast spadek Rosjan do 388 tys. 481 osób $^{370}$.

W 1959 r. W strukturze narodowościowej republiki Tadżykowie stanowili 53\%, zaś 1989 r. 62\%. Udział Uzbeków w latach 1959 - 1989 utrzymywał się na podobnym poziomie (ok. 23\%), zaś spadł udział Rosjan i pozostałych narodowości odpowiednio z 9\% w 1959 r. do ponad 7,6\% w 1989 r. oraz z 7,55\% w 1959 r. do 6,56\% w 1989 r. $^{371}$ (zob. Tabela 1).

Interesująca jest dynamika zmian populacji poszczególnych narodowości na tle całej populacji w republice. Wysoki odsetek populacji rdzennych narodowości (Tadżyków i Uzbeków), którzy zachowali tradycję wielodzietności, przyczyniał się do utrzymania stosunkowo wysokiego wskaźnika urodzeń. Między spisami powszechnymi w latach 1959 1989 liczba ludności republiki wzrosła o 157,27\%, natomiast Tadżyków aż o 201,8\%,

\footnotetext{
${ }^{365}$ Zob. T. Bodio, S. Isłomow, W. Śmidowski, Procesy demograficzne, op. cit. s 293.

366 Tadżycką SRR zamieszkiwało od blisko 80 narodowości w 1939 r. do ponad 120 w 1989 r. Dane za: Всесоюзная перепись...1939 і Всесоюзная перепись...1989.

${ }^{367}$ Dane za: Всесоюзная перепись... 1959.

${ }^{368}$ Dane za: Всесоюзная перепись...1970.

${ }^{369}$ Dane za: Всесоюзная перепись...1979.

${ }^{370}$ Dane za: Всесоюзная перепись...1989.

${ }^{371}$ Wyliczenia własne na podstawie: Всесоюзная перепись...1959 і Всесоюзная перепись...1989.
} 
Uzbeków o 163,9\%, a Rosjan posiadających niewielką liczbę dzieci wzrosła o 47,93\% (zob. Tabela 1).

Tabela 1. Udział wybranych narodowości w populacji Tadżykistanu w latach 1939 - 1989 (\%)

\begin{tabular}{|l|l|l|l|l|l|}
\hline \multicolumn{1}{|c|}{ Narodowość } & \multicolumn{1}{|c|}{$\mathbf{1 9 3 9}$} & \multicolumn{1}{c|}{$\mathbf{1 9 5 9}$} & \multicolumn{1}{c|}{$\mathbf{1 9 7 0}$} & \multicolumn{1}{c|}{$\mathbf{1 9 7 9}$} & \multicolumn{1}{c|}{$\mathbf{1 9 8 9}$} \\
\hline Tadżycy & 59,55 & 53,00 & 56,22 & 58,77 & 62,29 \\
\hline Uzbecy & 23,90 & 23,00 & 22,96 & 22,94 & 23,52 \\
\hline Rosjanie & 9,0 & 13,26 & 11,86 & 10,39 & 7,63 \\
\hline Pozostałe narodowości & 7,55 & 10,74 & 8,96 & 7,9 & 6,56 \\
\hline
\end{tabular}

Źródło: Opracowanie własne na podstawie danych za:Всесоюзная перепись...1939., Всесоюзная перепись...1959., Всесоюзная перепись...1970., Всесоюзная перепись...1979., Всесоюзная перепись...1989.

\section{Demografia Tadżykistanu w pierwszej dekadzie niepodległości}

Rozpad ZSRR doprowadził do ogromnego przepływu ludności ${ }^{372}$, m.in. skutkował migracją do historycznych ojczyzn (głównie do Rosji i Niemiec, w przypadku Tatarów krymskich - na Ukrainę) lub republik prowadzących aktywną politykę repatriacji mniejszości narodowych (np. do Polski i Izraela) ${ }^{373}$.

Lata 90. XX wieku cechowały się dalszym wzrostem populacji republiki. Trzeba jednak podkreślić, że wzrost ten nie był już tak dynamiczny, jak w czasach radzieckich. Podczas gdy w 1991 r. Tadżykistan zamieszkiwało ponad 5,5 mln osób, w 2000 r. było to już ponad 6,2 mln osób (wzrost o "zaledwie" 12,7\%, podczas gdy dekadę wcześniej odnotowano wzrost populacji o ponad 34\%). W latach 1991 - 2001 średnie tempo przyrostu naturalnego wynosiło $1,85 \%$, podczas gdy w latach 1980 - 1990 było ono na poziomie $3 \%{ }^{374}$.

Można wyróżnić wiele przyczyn pogorszenia się poziomu życia i wzrostu ubóstwa wśród ludności, które przełożyły się na sytuację demograficzną Tadżykistanu w latach 90. XX w. Wśród nich można wymienić m.in. dramatyczną w skutkach wojnę domową w latach 1992 - 1997 (zwaną niekiedy wojną pięciu klanów), która ujawniła niezwykle skomplikowane podziały socjopolityczne skutkujące konfliktem zbrojnym między dominującymi grupami

\footnotetext{
${ }^{372}$ А. Вишневский podaje, że w po upadku ZSRR $65 \mathrm{mln}$ osób pozostało poza granicami swoich ojczyzn. Zob. А. Вишневский, Демографический кризис в странах СНГ, Население и общество, 2005, № 197 - 198. http://www.demoscope.ru/weekly/2005/0197/s_map.php (20.04.2020).

${ }^{373}$ Zob. Демографическая ситуация в Таджикистане. Естественное и механическое движение населения u его социальные последствия. Центральная Азия и Кавказ, https://www.cac.org/datarus/st_08_bush_4.shtml (20.04.2020).

${ }^{374}$ Zob. T. Bodio, S. Isłomow, W. Śmidowski, Procesy demograficzne, op. cit., s. 293.
} 
etnopolitycznymi ${ }^{375}$. Trwający pięć lat konflikt zaciążył na transformacji gospodarczej, na którą nakładały się także konsekwencje zerwania powiązań gospodarczych z republikami byłego ZSRR ${ }^{376}$. Czynnikami, które również oddziaływały na sytuację społecznodemograficzną był kryzys gospodarczy w drugiej połowie lat 90. XX w. oraz migracja ludności będąca następstwem powyższych wydarzeń, które odcisnęły silne piętno na mentalności lokalnej ludności ${ }^{377}$.

W wojnie domowej, według różnych szacunków, zginęło ok. 100 tys. osób, za zaginionych zostało uznanych kolejne 100 tys., natomiast ponad $1 \mathrm{mln}$ ludzi opuściło Tadżykistan ${ }^{378}$. Większość $\mathrm{z}$ migrantów wróciła po wojnie do Tadżykistanu. Według R. S. Bobochonowa do połowy października 1997 r. ponad 90\% uchodźców wróciło do republiki $^{379}$. Z kolei straty gospodarcze tylko w latach 1992 - 1993 - jak pisze M. Lang - były szacowane przez władze Tadżykistanu na sumę 7 mld USD ${ }^{380}$. Spadek PKB, jaki miał miejsce w wyniku wojny, na co wskazuje N. Kajumow - przybrał rozmiary katastrofalne. W latach 1991 - 1996 PKB Tadżykistanu zmniejszył się o ponad $60 \%{ }^{381}$.

Warto odnotować, że wojna domowa wywarła ogromny wpływ również na społeczeństwo w wymiarach psychopolitycznym i kulturowym. Interesującej analizy w tym zakresie dokonali T. Bodio i I. Asadułłaew ${ }^{382}$. Wskazują oni, że zakończenie wojny domowej było dla społeczeństwa Tadżykistanu wyzwaniem egzystencjalnym. Sam zaś konflikt i jego koszty psychospołeczne zrodził kulturę antywojny ${ }^{383}$. Badacze zwracają uwagę, że rodząca się w Tadżykistanie nowa kultura polityczna stwarzała warunki dla konsolidacji narodowej oraz budowy świeckiego, demokratycznego państwa prawa ${ }^{384}$. Z dzisiejszej perspektywy widać wyraźnie, że nie zostały one efektywnie spożytkowane.

\footnotetext{
375 Bardzo dobrej analizy przyczyn, przebiegu, procesu pokojowego i skutków wojny domowej dokonał M. Lang. Zob. M. Lang, Wojna domowa i proces pokojowy w Tadżykistan, w: T. Bodio (red.), Tadżykistan. Historia..., op. cit. Warszawa 2002.

${ }^{376}$ Zob. T. Bodio, S. Isłomow, W. Śmidowski, Procesy demograficzne, op. cit., s. 293.

${ }^{377} \mathrm{Na}$ podstawie rozmów autora niniejszego artykułu z przedstawicielami administracji państowej Tadżykistanu, a także mieszkańcami Tadżykistanu.

${ }^{378}$ J. Lang podaje liczbę uchodźców i przesiedleńców wewnętrznych Tadżykistanu siegającą 1,2 mln osób. Zob. J. Lang, Tadżkistan: chroniczna stagnacja, Kometarze OSW, 2016.

379 Zob. Р. С. Бобохонов, Миграчионные процессы в Таджикистане (XX в.) и России, Политика и общество- Но4 (88), 2012.

${ }^{380}$ Zob. M. Lang, Wojna domowa..., op. cit.s. 181.

${ }^{381}$ Zob. N. Kajumow, W kierunku gospodarki rynkowej, s. 419 w: T. Bodio (red.), Tadżykistan. Historia..., op. cit. Warszawa 2002.

${ }^{382}$ Zob. I. Asadułłaew, T. Bodio, Psychopolityczne i kulturowe nastęstwa wojny domowej w: T. Bodio (red.), Tadżykistan. Historia..., op. cit. Warszawa 2002.

${ }^{383}$ Zob. I. Asadułłaew, T. Bodio, Psychopolityczne i kulturowe..., op. cit., s. 186-187.

${ }^{384}$ Zob.I. Asadułłaew, T. Bodio, Psychopolityczne i kulturowe..., op. cit., s. 195.
} 
Jak sygnalizowano, na konflikt $\mathrm{w}$ Tadżykistanie składał się również kryzys gospodarczy, który spotęgował i tak już ekstremalnie trudną sytuację Tadżykistanu. D. Rosati zwraca m.in. uwagę, że kryzysowi towarzyszyła inflacja ${ }^{385}$, która doprowadziła do wzrostu cen o ponad $1000 \%$. Realne dochody mieszkańców zmniejszyły się o $90 \%{ }^{386}$.

Trudna sytuacja w Tadżykistanie w pierwszej dekadzie po uzyskaniu suwerenności, wywarła wpływ na demografię, co jest m.in. widoczne na wskaźniku średniej długości życia mieszkańców. W latach 1991 - 2000 wahała się ona pomiędzy 70,1 a 68,2 lat. Najniższa średnia długość życia dla kobiet i mężczyzn przypadała na lata 1993 - 1994 tj. w trakcie i niedługo po zakończeniu otwartej fazy wojny domowej. Dla kobiet średnia długość życia wynosiła 68,1 lat, dla mężczyzn było to 56,4 lata. Na czas wojny przypada również największa liczba zgonów wśród mężczyzn w wieku produkcyjnym ${ }^{387}$. Dopiero w drugiej połowie lat 90. XX w. zaczęła rosnąć średnia długość życia mężczyzn i kobiet (zob. Tabela nr 2). Wydarzenia $\mathrm{w}$ dekadzie niepodległości również rzutowały na inne wskaźniki demograficzne, w tym spadek dzietności i wysoką śmiertelność dzieci poniżej pięciu lat ${ }^{388}$.

Tabela 2. Średnia długość życia mężczyzn i kobiet w latach 1991 - 2000

\begin{tabular}{|l|l|l|l|}
\hline Rok & \multicolumn{1}{|c|}{$\begin{array}{c}\text { Średnia dla calej } \\
\text { populacji }\end{array}$} & Średnia dla mężczyzn & Średnia dla kobiet \\
\hline 1991 & 70,1 & 67,3 & 72,9 \\
\hline 1992 & 68,2 & 65,4 & 71,1 \\
\hline 1993 & 61,8 & 56,4 & 68,1 \\
\hline 1994 & 65,0 & 62,5 & 67,6 \\
\hline 1995 & 66,1 & 63,5 & 68,9 \\
\hline 1996 & 68,8 & 64,0 & 69,8 \\
\hline 1997 & 67,6 & 64,9 & 70,5 \\
\hline 1998 & 68,1 & 65,7 & 70,5 \\
\hline 1999 & 68,6 & 66,3 & 70,9 \\
\hline 2000 & 68,2 & 66,1 & 70,3 \\
\hline
\end{tabular}

Źródło: Opracowanie własne na podstawie danych za: Основные демографические..., ор. cit.

\footnotetext{
${ }^{385}$ Warto zwrócić uwagę, na to co D. Rosati wskazuje w swoim artykule, że w latach 90-tych ubiegłego wieku w Tadżykistanie miały miejsce aż trzy inflacje.

${ }^{386}$ Zob. D. Rosati, Średniookresowa strategia przekształceń strukturalnych, ożywienia gospodarki i reform w: T. Bodio (red.), Tadżykistan. Historia..., op. cit. Warszawa 2002.

${ }^{387}$ Ponadto L. Sokołowa zwraca uwagę, iż 1993 r. w związku z konfliktem zbrojnym wzrosła śmiertelność z tytułu wypadków: zabójstw i samobójstw a także innych zdarzeń zewnętrznych. Людмила Соколова, Демографическое развитие Республики Таджикистан в переходный период, Центральная Азия и Кавказ, https://www.ca-c.org/journal/14-1998/st_05_sokolova.shtml (22.04.2020).

388 Średnia dla Tadżykistanu z lat 1990-1995 jesli chodzi śmiertelność dzieci do lat pięciu w Tadżykistanie była najwyższa wśród wszystkich republik środkowoazjatyckich i wynosiła 114 na 1000 . Dla Kazachstanu było to 61 na 1000, Kirgistanu - 72 na 1000, Turkmenistanu - 96 na 1000, Uzbekistanu - 74 na 1000. Dane za: World Population Prospects, 2017 Revison. Volume I: Comprehensive Tables, Department of Economic and Social Affairs Population Division, United Nations, New York, 2017, s. 218.
} 
Lata 90. XX w. to także zmiany w strukturze ludności miejskiej i wiejskiej. Nadal następował wzrost liczby mieszkańców wsi, natomiast liczba mieszkańców miast spadła. Spowodowało to jeszcze większą różnicę w procentowym udziale obydwu kategorii w całej populacji Tadżykistanu. Jeśli w 1991 r. podział ten wyglądał następująco: 30,8\% - ludność miejska, 69,2 - ludność wiejska, to w 2000 r. udział ludności miejskiej w całej populacji państwa zmniejszył się do poziomu 26,4\% przy wzroście udziału ludności wiejskiej do 73,6\%. Można więc skonstatować, że jedną $\mathrm{z}$ charakterystycznych cech procesów demograficznych lat 90. XX w. była zwiększająca się dysproporcja pomiędzy liczbą ludności wiejskiej a liczbą ludności miejskiej. Wpływ na to miał nie tylko większy przyrost naturalny ludności wiejskiej, ale również migracja ludności miejskiej na wieś, która była związana z postępującą dezurbanizacją w Tadżykistanie ${ }^{389}$.

\section{Wykres 2. Dynamika populacji ludności zamieszkującej w latach 1991 - 2000 na terytorium Tadżykistanu - w podziale na ludność miejską i wiejską}

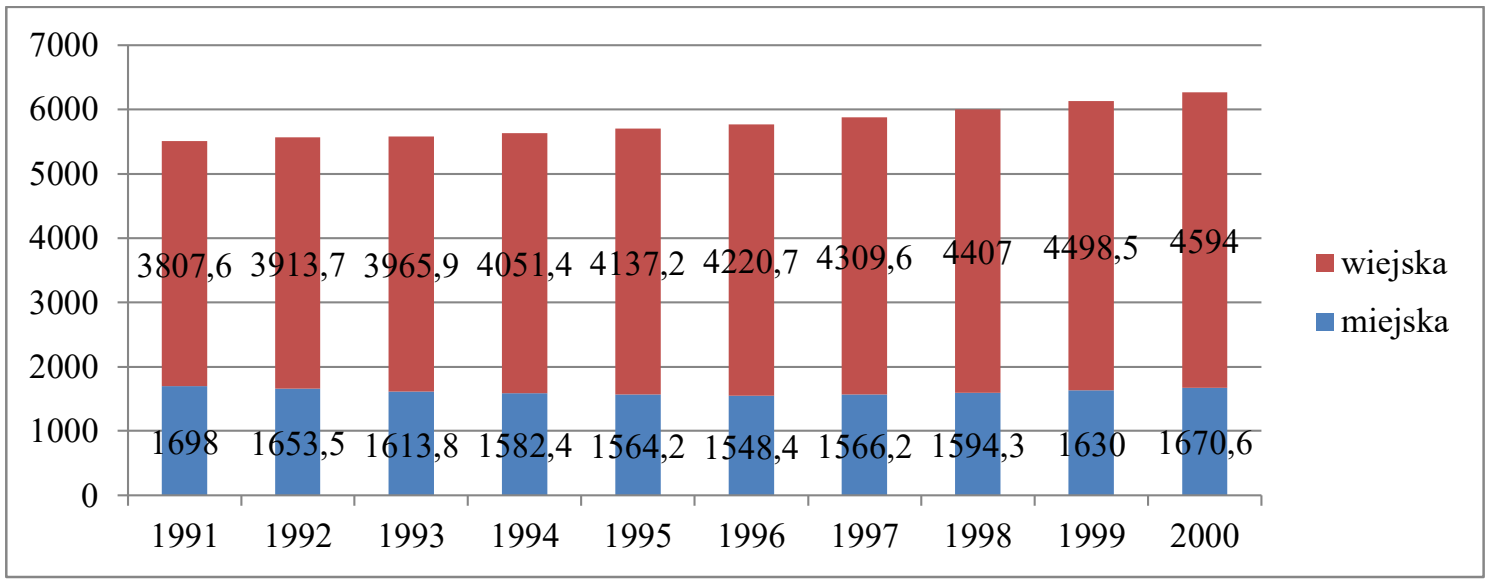

Źródło: Opracowanie własne na podstawie danych za: Основные демографические..., ор. cit.

W pierwszej dekadzie niepodległości Tadżykistanu można było również obserwować tendencję do dalszego spadku udziału kobiet w strukturze populacji. W $1991 \mathrm{r}$. udział kobiet wynosił 50,2\% a mężczyzn 49,8\%, w 1995 r. proporcje te się wyrównały i utrzymywały do 1998 r. Rok później zaczęły się one zmieniać na korzyść mężczyzn (zob. Tabela 3).

\footnotetext{
${ }^{389}$ Dezurbalizacja w latach 90. XX w. Tadżykistanie była skutkiem wojny domowej i kryzysu społecznogospodarczego, któremu towarzyszyło masowe przesiedlenie ludności zarówno wewnątrz kraju, jak i za granicę. W szczególności okres 1991-2001 charakteryzuje się dwiema falami migracji z Tadżykistanu ludności rosyjskojęzycznej, z których większość mieszkała w miastach. Pierwsza fala migracji miała miejsce w latach 1990-1991, zaraz po rozpadzie ZSRR. Powodem drugiej znacznie większej fali migracji w latach 1992-1995 była wojna domowa w Tadżykistanie. Zob. Урбанизация в Центральной..., op. cit. s. 23.
} 
Tabela 3. Udział kobiet i mężczyzn w populacji Tadżykistanu w latach 1991 - 2000 (\%)

\begin{tabular}{|l|c|c|c|c|c|c|c|c|c|c|}
\hline \multicolumn{1}{|c|}{ Rok } & $\mathbf{1 9 9 1}$ & $\mathbf{1 9 9 2}$ & $\mathbf{1 9 9 3}$ & $\mathbf{1 9 9 4}$ & $\mathbf{1 9 9 5}$ & $\mathbf{1 9 9 6}$ & $\mathbf{1 9 9 7}$ & $\mathbf{1 9 9 8}$ & $\mathbf{1 9 9 9}$ & $\mathbf{2 0 0 0}$ \\
\hline Kobiety & 50,2 & 50,2 & 50,1 & 50,1 & 50,0 & 50,0 & 50,0 & 50,0 & 49,1 & 49,1 \\
\hline Mężczyźni & 49,8 & 49,8 & 49,9 & 49,9 & 50,0 & 50,0 & 50,0 & 50,0 & 50,1 & 50,1 \\
\hline
\end{tabular}

Źródło: Opracowanie własne na podstawie danych za: Демографический ежегодник..., ор. cit. s. 30.

Kolejną osobliwością procesów demograficznych w latach 90. XX wieku w Tadżykistanie były zmiany w strukturze narodowościowej z korzyścią dla Tadżyków. Ze spisu ludności z 1989 r. wynika, że Tadżycy stanowili ok. 62,3\%, Uzbecy 23,5\%, Rosjanie $7,6 \%{ }^{390}$. Z kolei dane za rok 2000 pokazują, że udział Tadżyków w strukturze narodowościowej republiki wynosił 79,9\%, zaś Uzbeków spadł do 15,3\%, a Rosjan do $1,1 \%{ }^{391}$. Wpływ na zmiany w składzie narodowościowym miała wysoka dzietność w rodzinach rdzennych Tadżyków, a nade wszystko emigracja ludności narodowości nietytularnych.

\section{Dynamika zmian demograficznych we współczesnym Tadżykistanie}

Obecna sytuacja demograficzna Tadżykistanu, podobnie jak w czasach radzieckich, charakteryzuje się wysokim wzrostem populacji. W 2000 r. populacja republiki liczyła ponad 6,2 mln mieszkańców, zaś w 2011 r. wynosiła już ponad 7,8 mln. Na koniec 2018 r. populacja osiągnęła poziom przekraczający 9,1 mln osób. Ludność miejska stanowiła blisko 2,4 mln., zaś wiejska ponad $6,7 \mathrm{mln}$ ludności wiejskiej ${ }^{392}$. W ciągu 8 lat populacja Tadżykistanu zwiększyła się więc o ponad 1,3 mln osób (wzrost o ponad $16,6 \%)^{393}$.

\footnotetext{
${ }^{390}$ Zob. Всесоюзная перепись... 1989.

391 Zob. Dane za: Glenn E. Curtis, ed. Tajikistan: A Country Study. Washington: GPO for the Library of Congress, 1996. http://countrystudies.us/tajikistan/23.htm (05.05.2020).

${ }^{392}$ Dane za: Численность постоянного..., ор. cit.

${ }^{393} \mathrm{Z}$ najnowszych dostępnych danch wynika, że populacja Tadżykistanu wynosi ponad 9,4 mln osób. Zob. Население Таджикистана, https://countrymeters.info/ru/Tajikistan (15.05.2020).
} 


\section{Wykres 3. Dynamika populacji ludności zamieszkującej w latach 2011 - 2018 na terytorium Tadżykistanu - w podziale na ludność miejską i wiejską}

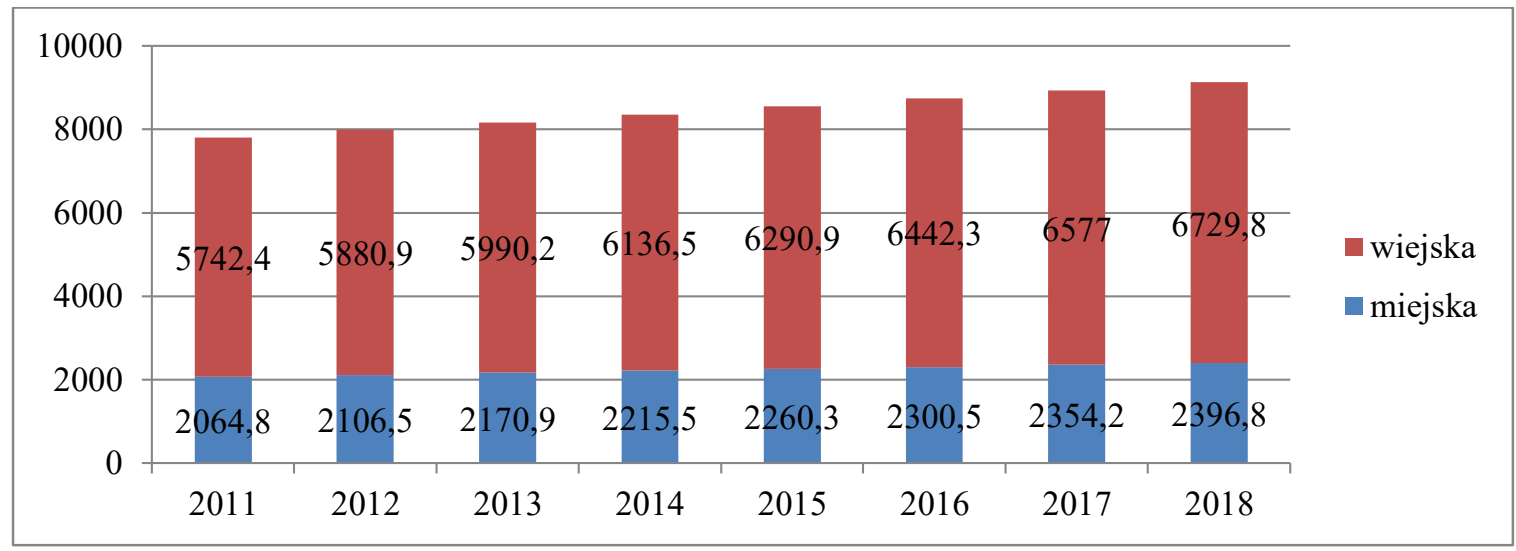

Źródło: Opracowanie własne na podstawie danych za:Численность постоянного..., op. cit.

\section{Ruch naturalny ludności}

$\mathrm{Na}$ ruch naturalny ludności składają się urodzenia, zgony, przyrost naturalny, małżeństwa oraz rozwody. W latach 2011 - 2018 w niewielkim stopniu zmniejszyła się liczba urodzeń - z 29,1 do 25,6 urodzeń na 1000 mieszkańców. Natomiast współczynnik przyrostu naturalnego spadł tylko nieznacznie, z 24,7\% w 2011 r. do 22,0\% w 2018 r., co było wynikiem dość wysokiego poziomu urodzeń na 1000 mieszkańców oraz niskiego - zgonów na 1000 mieszkańców (w 2011 r. na 1000 osób wyniosła 4,4, a w 2018 - 3,6) 394 $^{394}$.

Jeśli zaś chodzi o liczbę nowo urodzonych dzieci, w 2018 r. wynosiła ona 231 tys. i była wyższa niż w 2011 r., kiedy to urodziło się 224,2 tys. dzieci. Z kolei liczba zgonów spadła z 33,9 tys. w 2011 r. do 32,7 tys. w 2018 r. ${ }^{395}$. Wśród głównych przyczyn zgonów w 2017 r. znalazły się na pierwszym miejscu choroby układu krążenia, następnie inne choroby i nowotwory $^{396}$. Porównując do rozkładu przyczyn zgonów z 1970 r. do tego obecnego potwierdza się teza, że Tadżykistan jest w trakcie etapu - przejścia demograficznego charakterystycznego dla krajów rozwijających się $e^{397}$.

\footnotetext{
${ }^{394}$ Zob. Основные демографические..., ор. cit.

${ }^{395}$ Zob. Основные демографические..., op. cit.

${ }^{396}$ Zob. Демографический ежегодник..., op. cit., s. 143.

397 Zob. Д. Юсупов, Проблемь демографического развития Таджикистана,
} http://www.narodnaya.tj/index.php?option=com_content\&view=article\&id=7598\%3A2018-10-04-04-1026\&Itemid=216, (15.05.2020) 
Większość przyrostu ludności przypada na mieszkańców wsi, których udział w 2018 r. w populacji wyniósł 73,7\%. Analizując dane dotyczące liczby mieszkańców miast i wsi (zob. Wykres 3) można zaobserwować, że udział poszczególnych kategorii od kilku ostatnich lat utrzymuje się na zbliżonym poziomie ${ }^{398}$.

Elementem na który warto zwrócić uwagę w kontekście szybkiego przyrostu populacji jest współczynnik dzietności w Tadżykistanie. W 2017 r. był na poziomie 3,8 dzieci na jedną kobietę $^{399}$. Jest to oczywiście mniej niż było w czasach Tadżyckiej SRR, choć w rejonach wiejskich nadal liczba 6-7 dzieci przypadających na jedną kobietę nie jest czymś nadzwyczajnym. Badanie przeprowadzone w 2017 r. przez przedstawicielstwo Fundacji Eberta w Kazachstanie pokazało, że młodzi ludzie w Tadżykistanie chcieliby mieć między 3 a 4 dzieci $^{400}$, co może wskazywać na możliwość utrzymania się trendu w najbliższych latach dotyczącego liczby 3-4 dzieci w rodzinie. Interesujące rezultaty dało inne badanie zrealizowane wśród Tadżyczek w 2017 r. Pokazało ono m.in., że różnica między pożądaną a faktyczną liczbą dzieci maleje wraz ze wzrostem poziomu wykształcenia; że, różnica między pożądanym a faktyczną liczbą urodzeń jest nieco wyższa wśród kobiet mieszkających na obszarach wiejskich niż wśród tych mieszkających w miastach oraz, że różnica między pożądanymi a rzeczywistymi współczynnikami urodzeń również maleje wraz ze wzrostem poziomu życia ${ }^{401}$.

Warto odnotować, iż z wielodzietnością wiąże się również kwestia planowania rodziny i zdrowia kobiet w Tadżykistanie ${ }^{402}$. W 2019 r. władze Tadżykistanu przyjęły Państwowy program zdrowia reprodukcyjnego, który zakłada m.in. promowanie planowania

\footnotetext{
${ }^{398}$ Tendencja udziału ludność miejskiej na poziomie ok. 26,5\% w stosunku ludności wiejskiej ok. 73,5 w całej populacji Tadżykistanu sięga już początku lat 2000 - tych.

${ }^{399}$ W 2012 r. współczynnik dzietności również wynosił 3,8. Zob. Таджикистан. Медико-Демографическое Исследование 2017. Агентство по Статистике при Президенте Республики Таджикистан, Душанбе, Республика Таджикистан, Министерство Здравоохранения и Социальной Защиты Населения Республики Таджикистан, Душанбе, Республика Таджикистан, The DHS Program ICF Rockville, Maryland, USA. Душанбе 2018, s. 68.

${ }^{400}$ Stosunkowo niewielkie różnice są pomiędzy chłopcami a dziewczętami (odpowiednio 3,44 i 3,48), jak również pomiędzy mieszkańcami wsi i miast (odpowiednio 3,51 i 3,44). Zob. Молодежь Центральной Азии. Таджикистан. На основе социологического опроса. Представительство Фондаим. Фридриха Эберта в Казахстане, Алматы, 2017, s. 145.

${ }^{401}$ Таджикистан. Медико-Демографическое..., ор. cit. s. 85.

${ }^{402}$ Eksperci zwracają uwagę, że istotnym problemem jest to, że najczęściej kobiety tadżyckie rodzą dzieci jedno po drugim, uniemożliwiając w ten sposób prawidłowe wyzdrowienie ciała. Konsekwencją jest osłabienie zdrowia kobiet, brak czasu i finansów aby móc w większym stopniu zadbać o dzieci jeśli chodzi o ich edukację. Zob. Новая программа контрачепции: Минздрав взялся за таджиков, особенно за женщин.https://tj.sputniknews.ru/health/20190926/1029927303/tajikistan-kontratseptsiya-polovaya-etikasemiya.html (20.05.2020)
} 
rodziny, poprawę zdrowia kobiet, podejmowanie działań zapobiegających niechcianym ciążom ${ }^{403}$.

Zauważalny jest w latach 2011 - 2018 spadek zawieranych małżeństw oraz wzrost liczby rozwodów ${ }^{404}$. W 2011 r. zostało zawartych 94 tys. 730 małżeństw, podczas gdy w 2018 r. jedynie 82 tys. 647. Nastąpił również spadek wskaźnika liczby zawieranych małżeństw na 1000 osób z 12,3 w 2011 r. do 9,1 w 2018 r. ${ }^{405}$ Jeśli zaś chodzi o rozwody, w 2011 r. było ich 6 tys. 762, a w 2018 r. już 10 tys. 976. Nastąpił zatem nieznaczny wzrost wskaźnika rozwodów na 1000 osób - z 0,9 w 2011 r. do 1,1 w 2018 r. ${ }^{406}$. Świadczy to o zmianach, jakie dokonują się w społeczeństwie, które coraz chętniej przyjmuje wzorce liberalne, charakterystyczne dla świata zachodniego. Przyczyna takiego stanu rzeczy jest związana z masowymi zagranicznymi migracjami zarobkowymi ${ }^{407}$. Na zwiększającą się liczbę rozwodów, wpływ ma przede wszystkim właśnie zagraniczna migracja zarobkowa, która zdominowała w ostatnich latach krajobraz Tadżykistanu ${ }^{408}$. Głównymi przyczynami rozwodów jest przemoc domowa oraz trudności finansowe ${ }^{409}$. R. Ułmasow zwraca również uwagę, iż wyjazd mężczyzn poważnie komplikuje relacje między małżonkami, co prowadzi do stresu, głównie wśród kobiet, a nawet do rozpadu rodzin. Wynikająca z tego emocjonalna alienacja, duży dystans między małżonkami, trudna sytuacja ekonomiczna, w jakiej znajduje się rodzina, i zdrada - wszystko to staje się podstawą do rozwodu ${ }^{410}$. Innym powodem, który

\footnotetext{
${ }^{403}$ Władze Tadżykistanu zakładają, że realizacja Państwowego programu zdrowia reprodukcyjnego na lata 20192022 pozwoli w ciągu trzech lat zapobiec ponad 450 tys. przypadków niechcianej ciąży.

${ }^{404}$ Należy zwrócić uwagę, że w stosunku do roku 2017 liczba zawieranych małzeństw w 2018 r. wzrosła o 4009. Za wcześnie jest jednak mówić o jakimś trwałym trendzie.

${ }^{405}$ Dane za: Основные демографические..., op. cit.

${ }^{406}$ Dane za: Основные демографические..., op. cit.

${ }^{407}$ Zagraniczna migracja zarobkowa Tadżyków wiąże się również z tzw. wczesnymi małżeństwami. Wczesne małżeństwa mają szczególnie negatywne konsekwencje dla dziewcząt, które stały się żonami w młodym wieku: minimalne szanse na wykształcenie, zdobycie zawodu, samodzielne zarabianie pieniędzy, zwiekszają ryzyko znacznego pogorszenia ich życia, jeśli małżeństwo z mężczyzną, który wyjechał do pracy, rozpadnie się. Ponadto, jeśli małżenstwo nie zostało oficjalnie zarejestrowane, ale odbyła się ceremonia religijna, nie będzie ono uznawane za legalne w państwie świeckim. Zob. np. Таджикистан: ранние браки как следствие миграции,

https://www.bbc.com/russian/international/2013/03/130321_tajikistan_demographics $\quad(05.06 .2020) ; \quad$ Д. В. Полетаев, Трудовая мигращия в Россию и матримониальное поведение в странах Центральной Азии http://www.demoscope.ru/weekly/2013/0579/analit03.php (05.06.2020).

${ }^{408}$ Ciężko jest wskazać dokładną liczbę migrantów Tadżyckich. Szacuje się, że co roku może pracować za granicą od 600 tyś do $1 \mathrm{mln}$ Tadżyków. Głównym kierunkiem wyjazdów zagranicznych za pracą jest Rosja i Kazachstan. Zob. С. Рязанцев, Трудовая миграчия из Центральной Азии в Р оссию в контексте экономического кризиса. № 55 Валдайские Записки.

409 Zob. А. Акобиршоева, В Таджикистане стало меньше разводов. Радоваться еще рано? https://rus.ozodi.org/a/29685030.html (05.06.2020).

410 Zob. Р. Ульмасов, Влияние внешней миграции на брачность и разводимость мигрантов, https://russiancouncil.ru/blogs/rahmon-ulmasov/vliyanie-vneshney-migratsii-na-brachnost-i-razvodimostmigrantov/ (05.06.2020).
} 
oddziałuje na wzrost liczby rozwodów w ostatnim czasie, jest chęć otrzymania rosyjskiego obywatelstwa $^{411}$. W opinii niektórych par decydujących się na rozwód, będąc samemu łatwiej i szybciej można uzyskać rosyjskie obywatelstwo niż w przypadku bycia w związku małżeńskim ${ }^{412}$. W przypadku spadku liczby zawieranych małżeństw jest to również ściśle związane z procesami migracyjnymi Tadżyków, którzy wyjeżdżając do pracy głównie do Rosji coraz bardziej przejmują wzorce kulturowe Rosjan, tj. nie śpieszą się z zakładaniem rodzin, a relacje ze starszymi krewnymi budowane są na podstawie mniejszej zależności niż zwyczajowo jest to przyjęte w Tadżykistanie. Ponadto młodzi ludzie z Tadżykistanu, będąc $\mathrm{z}$ dala od swoich krewnych, przyzwyczajają się do niezależności. Znaczną część swoich zarobków zachowują dla siebie. Taki styl życia jest atrakcyjny dla coraz większej liczby Tadżyków. Trend ten dotyczy to zwłaszcza miast, które przyciągają pracowników migrujących $^{413}$.

Tabela 4. Ruch naturalny ludności Tadżykistanu w latach 2011-2018

\begin{tabular}{|l|l|l|l|l|l|l|l|l|}
\hline \multicolumn{1}{|c|}{ Rok } & $\mathbf{2 0 1 1}$ & $\mathbf{2 0 1 2}$ & $\mathbf{2 0 1 3}$ & $\mathbf{2 0 1 4}$ & $\mathbf{2 0 1 5}$ & $\mathbf{2 0 1 6}$ & $\mathbf{2 0 1 7}$ & $\mathbf{2 0 1 8}$ \\
\hline Urodzenia (tys.) & 224,2 & 219,3 & 209,4 & 229,5 & 237,5 & 230 & 224,1 & 231 \\
\hline Urodzenia na 1000 osób & 29,1 & 27,8 & 25,9 & 27,8 & 28,1 & 26,6 & 25,4 & 25,6 \\
\hline Zgony (tys.) & 33,9 & 32,9 & 31,7 & 32,9 & 33,5 & 34,1 & 32 & 32,7 \\
\hline Zgony na 1000 osób & 4,3 & 4,3 & 3,9 & 4,0 & 4,0 & 3,9 & 3,6 & 3,6 \\
\hline Przyrost naturalny (tys.) & 190,3 & 186,4 & 177,7 & 196,6 & 204 & 195,9 & 192,1 & 198,3 \\
\hline Przyrost naturalny \% & 24,8 & 23,5 & 22,0 & 23,8 & 24,1 & 22,7 & 21,7 & 22 \\
\hline Zawierane małżeństwa & 94730 & 97653 & 96989 & 95537 & 76956 & 72499 & 78638 & 82647 \\
\hline $\begin{array}{l}\text { Zawierane małżeństwa } \\
\text { na 1000 osób }\end{array}$ & 12,3 & 12,4 & 12,0 & 11,6 & 9,1 & 8,4 & 8,9 & 9,1 \\
\hline Rozwody & & & & & & & & 10976 \\
\hline
\end{tabular}

${ }^{411}$ Liczba obywateli Tadżykistanu, w odniesieniu do których podjęto decyzję o przyznaniu obywatelstwa rosyjskiego w okresie od stycznia do grudnia 2019 r. wyniosła 44707 osób na łączną liczbę 497817, co stanowi 8,9\%. Pod tym względem Tadżykistan zajmuje 3 miejsce za Ukrainą (299422 osób) i Kazachstanem (50492 osób) Zob. Отдельные показатели миграчионной ситуачии в Российской Федерацииза январь - декабрь 2019 года с распределением по странам мира, https://мвд.pф/Deljatelnost/statistics/migracionnaya. (05.06.2020).

412 Zob. В Таджикистане стали больще разводиться ради российского гражданства, https://regnum.ru/news/2572346.html (05.06.2020).

${ }^{413}$ Należy również odnotować, iż na przestrzeni ostatnich lat zmienił się skład migracji zarobkowej, który jest czynnkiem wpływającym na spadającą liczbę zawieranych małżeństw. Podczas gdy wcześniej członkowie rodziny wyjeżdżali za granicę do pracy, to ostatnio można zaobserwować trend wskazujący, iż wyjeżdżają coraz młodsi ludzie, którzy nie zdążyli jeszcze znaleźć żony i mieć dzieci. Wielu z nich próbuje znaleźć partnera w Rosji. Zob. Муж, отеи, мигрант: зависит ли таджикская экономика от семейных традичийhttps://tj.sputniknews.ru/analytics/20180516/1025565254/migrant-semya-ekonomika-tajikistan.html (05.06.2020). 


\begin{tabular}{|l|l|l|l|l|l|l|l|l|}
\hline Rozwody na 1000 osób & 0,9 & 0,9 & 1,0 & 1,1 & 1,0 & 1,0 & 1,1 & 1,1 \\
\hline
\end{tabular}

Źródło: Opracowanie własne na podstawie danych za: Основные демографические.., op. cit.

\section{Rozmieszczenie ludności według podziału administracyjnego}

Tadżykistan jest krajem, którego, aż 93\% terytorium zajmują góry należące do najwyższych systemów górskich. Oprócz warunków naturalnych, które implikują rozmieszczenie terytorialne ludności w Tadżykistanie, występuje szereg innych czynników, które w przeszłości również odgrywały istotną rolę. T. Bodio, S. Isłomow i W. Śmidowski wymieniają takie uwarunkowania jak: historyczne, religijne, ekonomiczne, kulturowe, polityczne, socjologiczne, ekologiczne, psychologiczne i edukacyjne ${ }^{414}$.

Według podziału administracyjnego państwo dzieli się na 4 wilajety i miasto wydzielone, którym jest stolica Duszanbe. W 2018 r. stolica zamieszkiwana była przez ponad 846 tys. 400 osób, co stanowi 9,27\% łącznej populacji Tadżykistanu. Natomiast najwięcej osób mieszka w Wilajecie Chatlońskim - 3 mln 274 tys. 900 osób (35,88\%), w Wilajecie Sogdyjskim - 2 mln 658 tys. 400 tys. osób (29,13\%), w Wilajecie Administrowanym Centralnie - 2 mln 120 tys. osób (23,23\%). Najmniej zamieszkaną częścią Tadżykistanu jest Górskobadachszański Wilajet Autonomiczny z populacją 226 tys. 900 osób $(2,49 \%)^{415}$.

\section{Wykres 4. Udział populacji poszczególnych regionów w lącznej populacji Tadżykistanu w 2018 r. (\%)}

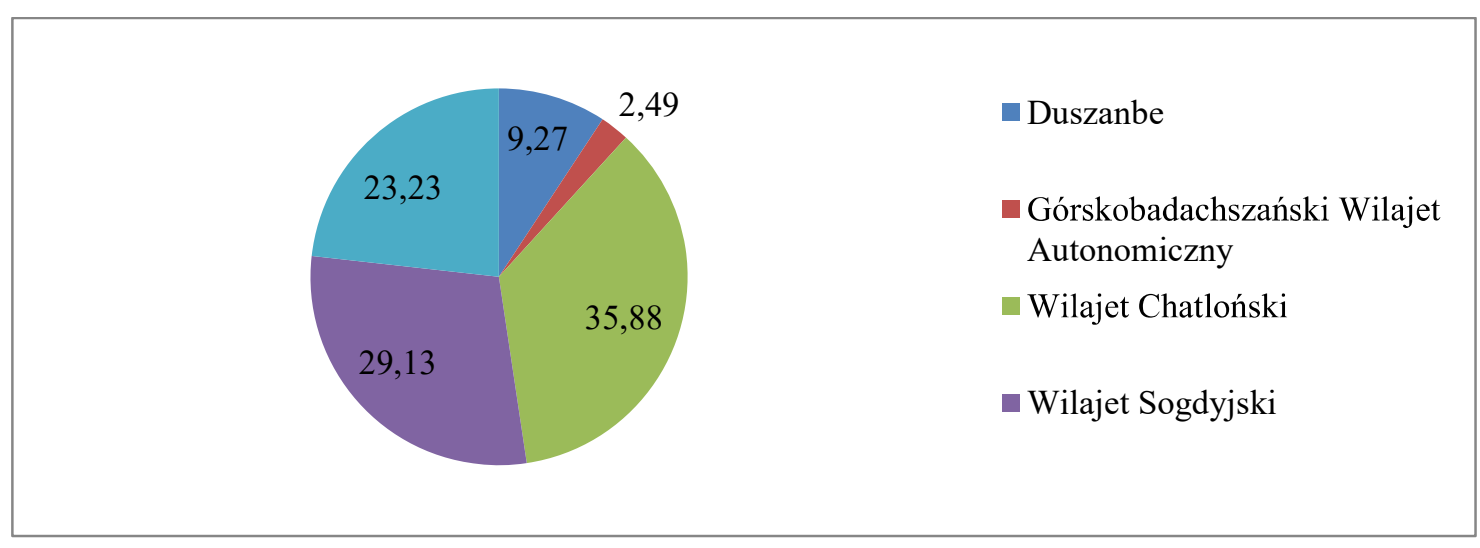

Źródło: Численность постоянного..., ор. cit.

\footnotetext{
${ }^{414}$ Zob. T.Bodio, S. Isłomow, W. Śmidowski, Procesy demograficzne..., op. cit. s 293.

${ }^{415}$ Dane za: Численность постоянного..., op. cit.
} 
Interesujące jest rozmieszczenie populacji w poszczególnych regionach Tadżykistanu w ujęciu na ludność miejską i wiejską. Największy, w ujęciu procentowym wzrost populacji miejskiej w latach 1991 - 2018 zanotował Wilajet Administrowany Centralnie (61,14\%), najmniejszy natomiast Wilajet Sogdyjski (20,54\%). Największy wzrost liczby ludności wiejskiej miał miejsce w Wilajecie Chatlońskim $(81,72 \%)$, najmniejszy w Górskobadachszańskim Wilajecie Autonomicznym $(31,23 \%)^{416}$.

Łącznie liczba osób mieszkających na obszarach wiejskich w Tadżykistanie wzrosła z 68,7\% w 1991 r. do 73,7\% w 2018 r. ${ }^{417}$. Zwiększająca się liczba ludności wiejskiej w porównaniu do liczby ludności miejskiej ${ }^{418}$ wynika nie tylko z większego przyrostu naturalnego o którym wcześniej była mowa. Istotnym czynnikiem wpływającym na tak dużą dysproporcję jest postępująca dezurbanizacja kraju ${ }^{419}$, która wraz wysokim bezrobociem i wzrostem kosztów utrzymania w miastach skutkują przymusową migracją na obszary wiejskie $^{420}$. Ponadto należy odnotować, iż rynek kredytów hipotecznych w Tadżykistanie istnieje $\mathrm{w}$ bardzo podstawowej formie, a pożyczki hipoteczne udzielane są tylko przez niektóre banki ${ }^{421}$. Jest to czynnik, który również nie sprzyja rozwojowi miast i przyciąganiu do nich mieszkańców wsi, a tym samym zmniejszaniu dysproporcji pomiędzy liczbą ludności miejskiej i wiejskiej.

Tabela 5. Dynamika zmian ludności miejskiej i wiejskiej Tadżykistanu w podziale na regiony w latach: 1991, 2000, 2011 i 2018

\begin{tabular}{|l|l|l|l|l|l|l|l|l|}
\hline & \multicolumn{3}{|c|}{ Ludność miejska } & \multicolumn{4}{c|}{ Ludność wiejska } \\
\hline Region & 1991 & 2000 & 2011 & 2018 & 1991 & 2000 & 2011 & 2018 \\
\hline Duszanbe & 584,3 & 564,0 & 731,1 & 831,4 & 0,00 & 0,00 & 0,00 & 0,00 \\
\hline
\end{tabular}

${ }^{416}$ Z danych wynika, iż w Duszanbe w latach 1991-2018 liczba ludności wzrosła o 247,1 tys. (wzrost o 42,29\%). Liczba ludności miejskiej Górskobadachszańskiego Wilajetu Autonomicznego wzrosła o 9 tys. osób (43,06\%), ludności wiejskiej o 46 tys. 100 tys. (31,23\%). Liczba ludności miejskiej Wilajetu Chatlońskiego wzrosła o 199 tys. 200 tys. osób (53,90\%), a liczba ludności wiejskiej o $1 \mathrm{mln} 182$ tys. 600 osób (81,72\%). Natomiast liczba ludności miejskiej Wilajetu Sogdyjskiego wzrosła o 110 tys. 200 osób (20,54\%), a liczba ludności wiejskiej o 864 tys. 600 osób (78,8\%). Z kolei liczba ludności miejskiej Wilajetu Administrowanego Centralnie wzrosła o 101 tys. osób (61,14\%), a liczba ludności wiejskiej o 810 tys. 600. osób $(81,68 \%)$. Wyliczenia własne na podstawie: Численность постоянного..., op. cit. oraz Демографический ежегодник..., op. cit. s. 25-26.

417 Dane za 1991 r. za: Демографический ежегодник, op. cit. s. 22., Dane za 2018 r. za: Удельный вес городского и сельского населения в общей численности населения, 2000-2018, Агентство по статистике при Президенте Республики Таджикистан.

${ }^{418} \mathrm{Na}$ cztery regiony w trzech liczba ludności wiejskiej wzrosła od $78,8 \%$ do $81,72 \%$ znacznie przewyższając wzrost liczby mieszkańców miast.

419 Tadżykistan ma najniższy poziom urbanizacji wśród krajów Azji Centralnej. Zob. Tajikistan. Country..., op. cit., s. 8.

420 Zob. M. Петрушков, Демографическая политика в Республике Таджикистан, https:/cabar.asia/ru/mihail-petrushkov-demograficheskaya-politika-v-respublike-tadzhikistan/ (15.06.2020).

${ }^{421}$ Zob. Tajikistan. Country..., op. cit., s. 41. 


\begin{tabular}{|l|l|l|l|l|l|l|l|l|}
\hline $\begin{array}{l}\text { Górskobadachszański } \\
\text { Wilajet } \\
\text { Autonomiczny }\end{array}$ & 20,9 & 27,5 & 28,1 & 29,9 & 147,6 & 178,8 & 178,4 & 193,7 \\
\hline Wilajet Chatloński & 369,6 & 374,4 & 467,0 & 568,8 & 1447,1 & 1770,8 & 2231,6 & 2629,7 \\
\hline Wilajet Sogdyjski & 536,5 & 497,2 & 560,3 & 646,7 & 1097,2 & 1374,6 & 1687,3 & 1961,8 \\
\hline $\begin{array}{l}\text { Wilajet } \\
\text { Administrowany } \\
\text { Centralnie }\end{array}$ & 165,2 & 166,9 & 234,0 & 266,2 & 992,4 & 1174,3 & 1503,4 & 1803,0 \\
\hline
\end{tabular}

Źródło: Opracowanie własne na podstawie danych za: Демографический ежегодник..., ор. cit.s. 25 - 27.

\section{Struktura populacji w ujęciu płci i wieku}

W strukturze ludności według płci począwszy od 2000 r. obserwujemy przewagę liczby mężczyzn, choć jeszcze latach $90 \mathrm{XX}$ w. to kobiety dominowały w strukturze populacji. W 2018 r. mężczyźni stanowili 50,7\% ogółu ludności, a kobiety $49,3 \%{ }^{422}$. Szczegółowe dane z lat 2011 - 2018 pokazujące utrzymujący się trend w tym zakresie ilustruje tabela 6 .

Tabela 6. Udział kobiet i mężczyzn w populacji Tadżykistanu (\%) w latach 1979, 1989, 2001 i 2011-2018

\begin{tabular}{|l|l|l|l|l|l|l|l|l|l|l|l|}
\hline \multicolumn{1}{|c|}{ Rok } & $\mathbf{1 9 7 9}$ & $\mathbf{1 9 8 9}$ & $\mathbf{2 0 0 1}$ & $\mathbf{2 0 1 1}$ & $\mathbf{2 0 1 2}$ & $\mathbf{2 0 1 3}$ & $\mathbf{2 0 1 4}$ & $\mathbf{2 0 1 5}$ & $\mathbf{2 0 1 6}$ & $\mathbf{2 0 1 7}$ & $\mathbf{2 0 1 8}$ \\
\hline Kobiety & 50,6 & 50,3 & 49,9 & 49,5 & 49,5 & 49,5 & 49,5 & 49,4 & 49,4 & 49,3 & 49,3 \\
\hline Mężczyźni & 49,4 & 49,7 & 50,1 & 50,5 & 50,5 & 50,5 & 50,5 & 50,6 & 50,6 & 50,7 & 50,7 \\
\hline
\end{tabular}

Źródło: Opracowanie własne na podstawie danych za: Демографический ежегодник..., ор. cit., s. 30.

W kontekście struktury populacji według płci warto zwrócić uwagę na zmieniające się proporcje między liczbą kobiet i liczbą mężczyzn w poszczególnych grupach wiekowych. Wśród ludności w grupach wiekowych od 0 do 39 lat przeważają mężczyźni. Natomiast w grupach wiekowych powyżej 39 lat, za wyjątkiem 70-74 lat, większość stanowią kobiety. Widać tu pewną prawidłowość - im starsza grupa ludności, tym bardziej kobiety przeważają nad mężczyznami pod względem liczebnym. Jest to związane $\mathrm{z}$ długością życia w Tadżykistanie - kobiety żyją średnio o ok 4 lata więcej niż mężczyźni ${ }^{423}$.

\footnotetext{
${ }^{422}$ Dane za: Демографический ежегодник..., op. cit., s. 30.

${ }^{423}$ Dane za: Демографический ежегодник..., op. cit., s. 36.
} 
Tabela 7. Populacja kobiet i mężczyzn w podziale na grupy wiekowe (2018 r.)

\begin{tabular}{|l|l|l|}
\hline \multicolumn{1}{|c|}{ Wiek } & \multicolumn{1}{|c|}{ Kobiety } & \multicolumn{1}{c|}{ Meqżczyźni } \\
\hline $0-9$ & 1054321 & 1149334 \\
\hline $10-14$ & 418503 & 441433 \\
\hline $15-19$ & 417182 & 438785 \\
\hline $20-24$ & 416063 & 432118 \\
\hline $25-29$ & 421661 & 425853 \\
\hline $30-34$ & 365930 & 370682 \\
\hline $35-39$ & 269363 & 275461 \\
\hline $40-44$ & 226199 & 224033 \\
\hline $45-49$ & 208750 & 202052 \\
\hline $50-54$ & 187033 & 178541 \\
\hline $55-59$ & 160064 & 153833 \\
\hline $60-64$ & 102575 & 95905 \\
\hline $65-69$ & 64846 & 59237 \\
\hline $70-74$ & 29664 & 29848 \\
\hline $75-79$ & 29730 & 27917 \\
\hline 80 i więcej & 30680 & 23599 \\
\hline & & \\
\hline & & \\
\hline
\end{tabular}

Źródło: Opracowanie własne na podstawie danych za: Демографический ежегодник..., ор. cit.s. 36.

Z dokonanej analizy struktury populacji Tadżykistanu w ujęciu wieku można wyciągnąć wniosek, że jest to społeczeństwo młode. W 2018 r. ponad 71\% stanowiły osoby do 34 roku życia. Porównując to do 2000 r. okazuje się, że osoby do 34 roku życia stanowiły $76,8 \%$ całej populacji Tadżykistanu, więc spadek rzędu niecałych $6 \% \mathrm{w}$ ciągu blisko 20 lat jest nieduży.

Osoby $\mathrm{w}$ wieku produkcyjnym stanowią $60 \%$ populacji, natomiast osoby $\mathrm{w}$ wieku emerytalnym zaledwie 5,7\%. Taki rozkład demograficzny jest bardzo korzystny dla gospodarki kraju, ponieważ Tadżykistan dysponuje ogromnym potencjałem zasobów pracy. Potencjał ten może mieć jednak również negatywną stronę - przy braku intensywnego tworzenia miejsc pracy - poziom bezrobocia może znacząco wzrosnąć. Dodatkowo sytuację komplikuje fakt, iż osób w wieku poniżej produkcyjnego jest bardzo dużo - ponad $3 \mathrm{mln}$ (34,3\% całej populacji Tadżyków). Stanowi to bazę do dalszego szybkiego wzrostu ludności 
republiki i jest swojego rodzaju „bombą z opóźnionym zapłonem” w przypadku braku zapewnienia odpowiedniej liczby miejsc pracy.

Ponadto, należy odnotować, iż Tadżykistan posiada korzystną struktura płci i wieku tj. proporcjonalny rozkład mężczyzn i kobiet w aktywnym wieku rozrodczym. Taki rozkład tworzy duży potencjał reprodukcyjny dla reprodukcji populacji. Jest to kolejny element świadczący o dużym potencjale demograficznym republiki, ale również pokazujący jak dużym wyzwaniem jest umiejętność efektywnego zarządzania demografią, która silnie jest związana z sytuacją gospodarczą.

Wykres 5. Średnia długość życia mieszkańców Tadżykistanu w latach 2001 - 2018

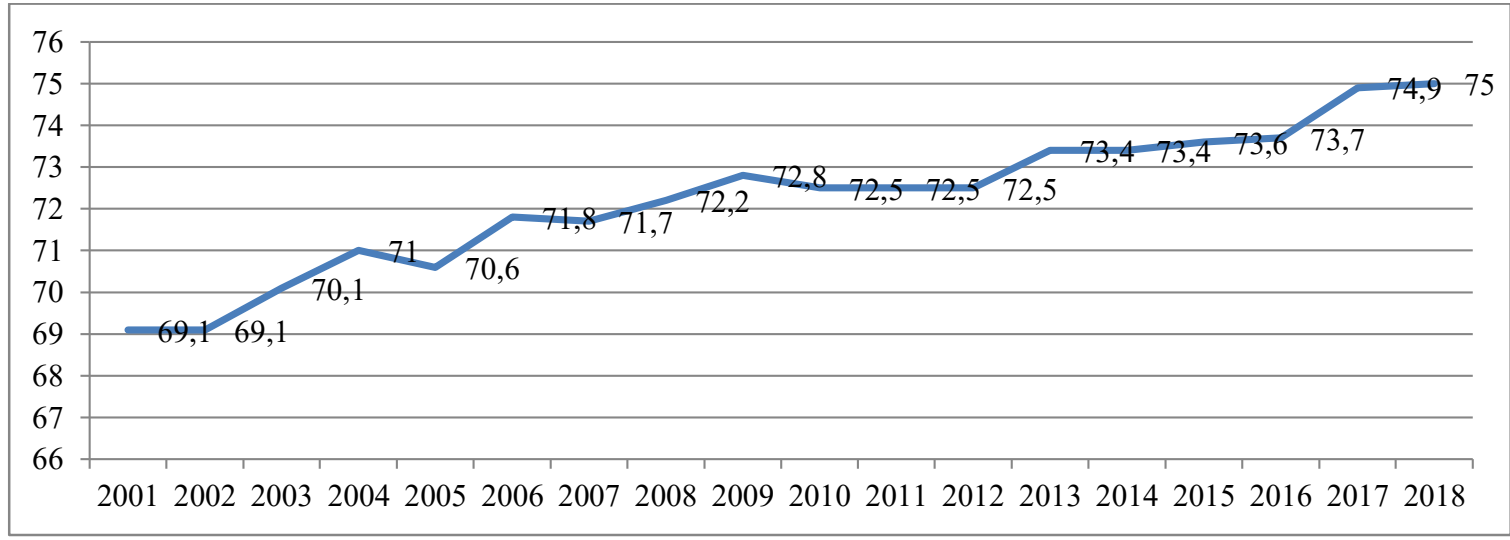

Źródło: Opracowanie własne na podstawie danych za: Основные демографические..., ор. cit.

Wskaźnikiem, który na przestrzeni lat uległ poprawie jest średnia długość życia Tadżyków. Proces wydłużania się długości życia rozpoczął się już w czasach ZSRR, by wyhamować w latach $90 \mathrm{XX}$ w., a następnie w kolejnych latach ponownie systematycznie rosnąć. Średnia długość życia dla całej populacji Tadżykistanu z 69,1 lat w 2001 r. wydłużyła się do 75 lat w 2018 r. $^{424}$. Wpływ na to ma rosnący poziom opieki zdrowotnej w Tadżykistanie $^{425}$ i zmniejszający się poziom ubóstwa, który jeszcze w 1999 r. wynosił 81\%, w 2012 r. 37,4\%, a w 2018 spadł do poziomu 27,4\% ${ }^{426}$. Należy podkreślić, że istnieją znaczne

\footnotetext{
${ }^{424}$ Dane za: Основные демографические..., ор. cit.

${ }^{425}$ Jako przykład można podać następujące dokumenty rządowe, które świadczą o tym, że władze Tadżykistanu zdają sobie sprawę z wagi temau jakim jest ochrona zdrowia obywateli: Начиональная стратегия здоровья населения Республики Таджикистан на 2010-2020 годы, Программа развития семейной медицины в Республике Таджикистан на 2011 - 2015.

426 Dane za 1999 r. za: Национальный Доклад о Человеческом Развитии 2014: Таджикистан: доступ к ресурсам для человеческого развития, Фонд Организации Объединенных Наций в области народонаселения (UNFPA) и Международная организация труда (ILO), Душанбе, 2015, dane za 2012 r. i 2018

r. $\quad$ za :

Бедность

Таджикистане

2019 ,
} 
różnice w poziomie ubóstwa w poszczególnych regionach Tadżykistan ${ }^{427}$, choć zjawisko to częściej występuje w rejonach wiejskich $(30,2 \%)$ niż miejskich $(21,5 \%)^{428}$.

\section{Uwagi końcowe}

Tadżykistan to państwo, które pomimo niekorzystnych warunków naturalnych posiada bardzo dobrą sytuację demograficzną. Wpływ na nią na przestrzeni lat miały uwarunkowania geograficzne, historyczne, religijne, ekonomiczne, kulturowe, polityczne, socjologiczne, ekologiczne, psychologiczne i edukacyjne.

Dla Tadżyckiej SRR w wymiarze demograficznym znamiennym był bardzo dynamicznym wzrost populacji (na przestrzeni 64 lat, od 1925 r. do 1989 r. wzrost na poziomie 413\%). Duża dynamika przyrostu populacji Tadżyckiej SRR w pierwszych latach jej funkcjonowania wynikała przede wszystkim $\mathrm{z}$ powiększenia się jej terytorium, a w kolejnych dekadach była związana z wysoką liczbą urodzeń dzieci przypadającej na jedną kobietę (między 4 a 6,3 urodzeń), wzrostu wskaźnika długości życia, oraz poprawy opieki zdrowotnej. Dodatkowym elementem sprzyjającym dynamicznemu wzrostowi populacji były tradycje posiadania wielodzietnej rodziny oraz polityka władz radzieckich. Skład etniczny również ulegał zmianom - największą liczbę mieszkańców Tadżyckiej SRR stanowili Tadżykowie (udział w całej populacji wahał się pomiędzy 59\% a $63 \%$ populacji), Uzbecy (udział w całej populacji utrzymywał się na stałym poziomie 23\%), Rosjanie (udział w całej populacji wahał się pomiędzy $9 \%$ a nieco ponad 13\%). Stosunkowo wysoki odsetek populacji rdzennych narodowości (Tadżyków i Uzbeków) był związany z tradycją posiadania wielu dzieci, co wpływało na szybsze tempo wzrostu ludności rdzennych narodowości niż całej populacji.

Lata 90. ubiegłego wieku charakteryzują się dalszym wzrostem populacji. Nie był on już tak dynamiczny, jak można to było obserwować w czasach radzieckich. Było to wynikiem pogorszenia się poziomu życia i wzrostu ubóstwa wśród ludności. W pierwszej dekadzie niepodległości Tadżykistan musiał nie tylko zmierzyć się z transformacją gospodarki z centralnie planowanej na wolnorynkową, ale również kryzysem politycznym, który w

https://www.vsemirnyjbank.org/ru/news/infographic/2019/10/17/poverty-in-tajikistan-2019

(15.06.2020).

Eksperci Banku Światowego zwracają uwagę, że poziom ubóśtwa zmienia się w ciągu roku. Wpływ na wahania ma liczba dostępnych miejsc pracy i pieniędzy przesyłanych przez migrantów zarobkowych.

427 Poziom ubóstwa w regionach Tadżykistanu przedstawiał się następująco: Sogdyjski Wilajet $(17,5 \%)$, Duszanbe (23,5\%), Górskobadachszański Wilajetu Autonomiczny (27,5\%), Chatloński Wilajet (32,7\%), Wilajet Administrowany Centralnie (33,2\%).

428

Zob. Бедность

B

Таджикистане

2019.

https://www.vsemirnyjbank.org/ru/news/infographic/2019/10/17/poverty-in-tajikistan-2019 (15.06.2020). 
konsekwencji doprowadził do wybuchu wojny domowej. Na to wszystko nałożył się kryzys gospodarczy. Skutkiem ww. wydarzeń były procesy dezurbanizacyjne i dezindustrializacyjne i masowa migracja ludności (ok. $1 \mathrm{mln}$ osób). Charakterystycznymi cechami sytuacji demograficznej Tadżykistanu w latach 90-tych XX w. była: zwiększająca się dysproporcja pomiędzy liczbą ludności wiejskiej, a liczbą ludności miejskiej, zmniejszająca się przewaga udziału kobiet w całej populacji, zmiany w jej strukturze narodowościowej (wzrost udziału Tadżyków o blisko $18 \%$ do poziomu 79,9\%), obniżenie się średniej długości życia (szczególnie w odniesieniu do mężczyzn), wysoki poziom dzietności, a także wysoki poziom umieralności dzieci poniżej piątego roku życia na 1000 urodzeń na tle innych republik środkowoazjatyckich.

Chociaż społeczeństwo w Tadżykistanie podlega ciągłym przemianom, tj. spada liczba zawieranych małżeństw, rośnie liczba rozwodów, a migracje zdominowały krajobraz tego państwa, to obecna sytuacja demograficzna $z$ punktu widzenia bezpieczeństwa demograficznego państwa jest dobra. Społeczeństwo tadżyckie posiada bardzo korzystną strukturę wieku populacji (osoby do 34 roku życia stanowią aż $71 \%$ całej populacji). Średnia przyrostu naturalnego $\mathrm{w}$ ostatnich latach kształtuje się na poziomie 192 tys. narodzonych dzieci. Dzietność utrzymuje się na wysokim poziomie (średnia z lat 2010-2015 to 3,5) i poziom umieralności dzieci do lat pięciu sukcesywnie od lat 90-tych XX w. spada. Ponadto, cechą charakterystyczną obecnej sytuacji demograficznej jest utrzymujący się już od blisko 20 lat wysoki odsetek ludności wiejskiej na poziomie 73,5\%, a także spadający udział kobiet w populacji. Należy jednak mieć na uwadze, że pomimo korzystnych wskaźników demograficznych, zagrożeniem dla trwałości rodziny stanowiącej w Tadżykistanie istotny komponent społeczeństwa, może być rosnąca liczba rozwodów i spadająca liczba zawieranych małżeństw.

Ponieważ w Tadżykistanie utrzymują się czynniki i warunki związane z wysokim współczynnikiem urodzeń przy stosunkowo niskim wskaźniku umieralności oraz długość życia ludzi systematycznie wydłuża się, można założyć, że populacja tego państwa będzie nadal rosła, co również potwierdzają prognozy ONZ. Jeśli prognoza ONZ w wariancie umiarkowanym sprawdziłaby się, w $2100 \mathrm{r} \mathrm{w}$ Tadżykistanu będzie żyło blisko $19 \mathrm{mln}$ osób.

Należy mieć na uwadze, że zbyt dynamiczny wzrost populacji, jeśli nie idzie za nim rozwój gospodarczy, może wywoływać negatywne konsekwencje dla państwa, tj. prowadzić do pojawienia się problemów związanych m.in. z zatrudnieniem, zwiększać bezrobocie, wpływać na ogólne obniżenie się poziomu życia, a także zwiększać socjalne napięcie w społeczeństwie. Eksperci Banku Światowego zwracają uwagę, że główną przyczyną 
bezrobocia i ubóstwa w Tadżykistanie jest właśnie bardzo szybki wzrost populacji i postulują ograniczenie przyrostu naturalnego ${ }^{429}$. W tym obszarze władze Tadżykistanu poczyniły pewne działania przyjmując w 2019 r. Państwowy program zdrowia reprodukcyjnego, który zakłada m.in. promowanie planowania rodziny ${ }^{430}$. Jest to krok w dobrym kierunku. Należy jednak wskazać, że nowa koncepcja w zakresie uregulowania całej polityki demograficznej nie została opracowana, choć poprzednia Koncepcja polityki demograficznej państwa Republiki Tadżykistan na lata $2003-2015^{431}$ przyniosła pewne pozytywne efekty w ograniczeniu dynamiki przyrostu naturalnego ${ }^{432}$.

Analizując demografię $\mathrm{i}$ jej ścisły związek $\mathrm{z}$ gospodarką i rynkiem pracy $\mathrm{w}$ Tadżykistanie nasuwa się pytanie: co $\mathrm{w}$ przypadku, kiedy gospodarka nie jest w stanie stworzyć odpowiednich warunków dla zatrudnienia swoich obywateli, a efekty ograniczania liczby urodzeń nie są wystarczające? Okazuje się, że wyjściem może być migracja ludności, ale tylko do pewnego stopnia i, co należy podkreślić, wyłącznie w krótkoterminowej perspektywie.

Tadżykistan jest przykładem państwa, który mając korzystną sytuację demograficzną, a jednocześnie nie będąc $\mathrm{w}$ stanie odpowiedniej liczby miejsc pracy dla swoich obywateli, zdecydował się na wykorzystanie migracji dla rozwiązania problemu nadwyżki siły roboczej. Warto przy tym zwrócić uwagę, iż migracja zarobkowa Tadżyków ma pozytywny wpływ na państwo i migrantów. $Z$ drugiej jednak strony wiążą się z nią liczne zagrożenia dotyczące zarówno państwa, społeczeństwa, jak samych migrantów i ich rodzin, które mogą być trudne do wyeliminowania bez wprowadzenia odpowiednich rozwiązań.

429 Zор. Рожать или не рожать: надо ли Таджикистану сдерживать рост населения, https:/www.vsemirnyjbank.org/ru/news/infographic/2020/04/27/tajikistan-macro-poverty-outlookspring-2020 (02.05.2020)

${ }^{430}$ Władze Tadżykistanu zakładają, że realizacjaPaństwowego programu zdrowia reprodukcyjnego na lata 20192022 pozwoli w ciągu trzech lat zapobiec ponad 450 tys. przypadków niechcianej ciąży.

431 Zob. Постановление "О Концепции государственной демографической политики Республики. Таджикистанна 2003-2015 г2.

http://www.gender.cawater-info.net/publications/pdf/law_rt_4_ru.pdf (02.05.2020).

${ }^{432} \mathrm{Na}$ koniec 2015 r., kiedy zakończył obowiązywać dokument wskaźnik urodzeń zaczął stopniowo spadać (współczynnik dzietności, według ONZ, spadł z 4,5 dzieci do jedna kobieta w 2000 r. do 3,5 w 2015 r.). Należy wskazać, że politykę demograficzną państwa wspierała głównie wykształcona część ludności miejskiej. Mieszkańcy wsi, tak jak poprzednio, uważali działania związane z planowaniem rodziny za ingerencję w „wolę Wszechmogącego" i naruszenie tradycji. Dodatakowo sytuację skomplikowało nasilenie procesów dezurbanizacji z którymi wiązał się odpływ mieszkańców miast na wieś. Tradycyjne wartości na wsi trzymają się mocniej, kobiety są mniej wykształcone i bardziej zależne od mężów, zaś na dzieci patrzy się przez pryzmat ekonomii, ponieważ dodatkowe ręce do pracy mają większe znaczenie niż w mieście. Zob. А. Козырева, Демографическая аномалия. Сколько миллионов сограждан нужно Эмомали Рахмону для всеобщего счастья.https://www.fergananews.com/articles/9984 (02.05.2020). 


\section{Streszczenie:}

W opracowaniu wskazuje się na tendencje i specyfikę procesów demokraficznych w Tadżykistnie. Jako punkt wyjścia autor wybrał czasy Tadżyckiej SRR, kiedy to rozpoczął się dynamiczny wzrost populacji. Autor omawia dynamikę zmian demograficznych w latach 90tych XX, która z uwagi na wojną domowej w Tadżykistanie w latach 1992 - 1997, transformację gospodarki $\mathrm{z}$ centralnie planowanej na wolnorynkową a także zerwaniu powiązań gospodarczych z republikami byłego ZSRR, znacznie zmalała. Główny akcent kładzie na wyjaśnieniu współczesnej sytuacji demograficznej. Zwraca uwagę, iż Tadżykistan jest przykładem państwa, który mając bardzo korzystną sytuację demograficzną, a jednocześnie nie będąc $\mathrm{w}$ stanie zapewnić możliwości zatrudnienia swoich obywateli, zdecydował się na wykorzystanie migracji dla rozwiązania problemu nadwyżki siły roboczej.

\section{Słowa kluczowe:}

Tadżykistan, Tadżycka SRR, demografia, procesy demograficzne, populacja, ruch naturalny ludności, stuktura ludności, skład narodowościowy populacji, migracja ludności

\section{Key words:}

Tajikistan, Tajik SSR, demographic, demographic processes, population, vital statistic, population structure, national composition of the population, migration

\section{Bibliografia:}

1. Акобиршоева Афсона, В Таджикистане стало меньше разводов. Радоваться еще рано? https://rus.ozodi.org/a/29685030.html

2. An overview of the World Bank's work in Tajikistan. Country Snapshot, April 2020. http://pubdocs.worldbank.org/en/417161587043463422/Tajikistan-SnapshotApr2020.pdf

3. Asadułłajew Iskandar, Bodio Tadeusz, Psychopolityczne i kulturowe następstwa wojny domowej, w: T. Bodio (red.), Tadżykistan. Historia, społeczeństw, polityka, Warszawa 2002.

4. В Таджикистане стали больще разводиться ради российского гражданства, https://regnum.ru/news/2572346.html

5. Бедность в таджикистане 2019, https://www.vsemirnyjbank.org/ru/news/infographic/2019/10/17/poverty-in-tajikistan2019 
6. Вишневский Анатолий, Демографический кризис в странах СНГ, Население и

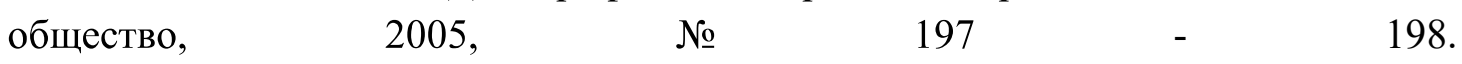
http://www.demoscope.ru/weekly/2005/0197/s_map.php

7. Bodio Tadeusz, Isłomow Sadułło, Śmidowski Witold, Procesy demograficzne w: T. Bodio (red.), Tadżkistan. Historia, społeczeństw, polityka, Warszawa 2002.

8. Всесоюзная перепись населения 1939 года.

9. Всесоюзная перепись населения 1959 года.

10. Всесоюзная перепись населения 1970 года.

11. Всесоюзная перепись населения 1979 года.

12. Всесоюзная перепись населения 1989 года.

13. Бобохонов Рахимбек Сархадбекович, Миграционные прочессы в Таджикистане (XX в.) и России, Политика и общество - Ho4 (88), 2012.

14. Соколова Людмила, Демографическое развитие Республики Таджикистан в nереходный период, Центральная Азия и Кавказ, https://www.ca-c.org/journal/141998/st_05_sokolova.shtml

15. Curtis Glenn E., ed. Tajikistan: A Country Study. Washington: GPO for the Library of Congress, 1996.http://countrystudies.us/tajikistan/23.htm

16. Демографическая ситуация в Таджикистане. Естественное и механическое движение населения и его сочиальные последствия. Центральная Азия и Кавказ, https://www.ca-c.org/datarus/st_08_bush_4.shtml

17. Демографический ежегодник Республики Таджикистан, Душанбе 2019.

18. GDP per capita (current US\$) - Tajikistan, Uzbekistan, Kyrgyz Republic, Turkmenistan, Kazakhstan, World Bank Data, 2018.

19. Касымова София, Традиция многодетного материнства у таджиков в контексте гендера и времени. Вестник Евразии. №4 (34). М., 2006.

20. Kajumow Nurridin, W kierunku gospodarki rynkowej, w: T. Bodio (red.), Tadżykistan. Historia, społeczeństw, polityka, Warszawa 2002.

21. Козырева Анна, Демографическая аномалия. Сколько миллионов сограждан нужно Эахмону Эмомали для всеобщего счастья.https://www.fergananews.com/articles/9984

22. Краткая информация о текущей ситуации в экономике Республики Таджикистанза 2019 год.https://www.medt.tj/ru/makroekpnpmika/sostoyanie/1203nati-a-oi-rushdi-i-timoiyu-i-tisodii-um-urii-to-ikiston-dar-nimsoli-yakumi-soli-2019

23. Lang Józef, Tadżykistan: chroniczna stagnacja, Kometarze OSW, 2016.

24. Lang Maciej, Wojna domowa i proces pokojowy w Tadzykistanie, w: T. Bodio (red.), Tadżykistan. Historia, społeczeństw, polityka, Warszawa 2002.

25. Молодежь Центральной Азии. Таджикистан. Наоснове соииологического onpoca. ПредставительствоФондаим. Фридриха Эберта в Казахстане, Алматы, 2017.

26. Муж, отеи, мигрант: зависит ли таджикская экономика от семейных традищий https://tj.sputniknews.ru/analytics/20180516/1025565254/migrant-semyaekonomika-tajikistan.html

27. Наџиональная стратегия здоровья населения Республики Таджикистан на 20102020 годы 
28. Начиональный Доклад о Человеческом Развитии 2014: Таджикистан: доступ к ресурсам для человеческого развития, Фонд Организации Объединенных Наций в области народонаселения (UNFPA) и Международная организация труда (ILO), Душанбе, 2015

29. Население Таджикистана, https://countrymeters.info/ru/Tajikistan

30. Новая программа контрацепции: Минздрав взялся за таджиков, особенно за женщин.https://tj.sputniknews.ru/health/20190926/1029927303/tajikistankontratseptsiya-polovaya-etika-semiya.html

31. Отдельные показатели миграчионной ситуации в Российской Федерации за январь - декабрь 2019 года с распределением по странам мира, https://мвд.рф/Deljatelnost/statistics/migracionnaya.

32. Основные демографические показатели, 1991-2018, Агентство по статистике при Президенте Республики Таджикистан.

33. Основные показатели развития здравоохранения, 1991-2018, Агентство по статистике при Президенте Республики Таджикистан.

34. Переводы из России, осуществленные через системы денежных переводовс I квартала 2014 г. по IV квартал 2018 2., http://www.cbr.ru/statistics/macro_itm/tg/

35. Петрушков Михаил, Демографическая политика в Республике Таджикистан, https://cabar.asia/ru/mihail-petrushkov-demograficheskaya-politika-v-respubliketadzhikistan/

36. Полетаев Дмитрий Вячеславович, Трудовая миграция в Россию $и$ матримониальное поведение в странах Центральной Азии http://www.demoscope.ru/weekly/2013/0579/analit03.php

37. Постановление "О Концепции государственной демографической политики Республики. Таджикистанна 2003-2015 г2." http://www.gender.cawaterinfo.net/publications/pdf/law_rt_4_ru.pdf

38. Программа развития семейной медииины в Республике Таджикистан на 2011 2015

39. Рожать или не рожать: надо ли Таджикистану сдерживать рост населения, https://www.vsemirnyjbank.org/ru/news/infographic/2020/04/27/tajikistanmacro-poverty-outlook-spring-2020

40. Рязанцев Сергей, Трудовая миграџия из Центральной Азии в Россию в контексте экономического кризиса. № 55 Валдайские Записки.

41. Rosati Dariusz, Średniookresowa strategia przeksztatceń strukturalnych, ożywienia gospodarki i reform, w: T. Bodio (red.), Tadżykistan Historia, społeczeństw, polityka, Warszawa 2002.

42. Таджикистан: Экономический меморандум по стране 2019, https://www.vsemirnyjbank.org/ru/news/infographic/2019/08/30/tajikistan-cem-2019

43. Таджикистан. Медико-Демографическое Исследование 2017. Агентство по Статистике при Президенте Республики Таджикистан Душанбе, Республика Таджикистан, Министерство Здравоохранения и Социальной Защиты Населения Республики Таджикистан Душанбе, Республика Таджикистан, The DHS Program ICF Rockville, Maryland, USA. Душанбе 2018. 
44. Таджикистан: ранние браки как следствие мигращии, https://www.bbc.com/russian/international/2013/03/130321_tajikistan_demographics

45. Tajikistan: Youth unemployment rate from 1999 to 2019, https://www.statista.com/statistics/813092/youth-unemployment-rate-in-tajikistan/

46. Tajikistan. Country Economic Memorandum. Nurturing Tajikistan's Growth Potential. Macroeconomics, Trade and Investment Global Practice, Europe and Central Asia Region. Washington 2019. s. xiv i xv.

47. Ульмасов Рахмон, Влияние внешней миграции на брачность и разводимость мигрантов, $\quad \mathrm{https} / /$ russiancouncil.ru/blogs/rahmon-ulmasov/vliyanie-vneshneymigratsii-na-brachnost-i-razvodimost-migrantov/

48. Удельный вес городского и сельского населения в общей численности населения, 2000-2018,Агентство по статистике при Президенте Республики Таджикистан.

49. Unemployment, total (\% of total labor force) (modeled ILO estimate) Tajikistan, https://data.worldbank.org/indicator/SL.UEM.TOTL.ZS?locations=TJ

50. Урбанизачия в Центральной Азии: вызовы, проблемы и перспективы. Аналитический доклад 2013/03,ЦЭИ, ЭСКАТО и ПРООН, Ташкент 2013.

51. Юсупов Джамшед, Проблемы демографического развития Таджикистана, $\mathrm{http}: / / \mathrm{www}$. narodnaya.tj/index.php?option $=$ com_content\&view $=$ article\&id $=7598 \% 3 \mathrm{~A}$ 2018-10-04-04-10-26\&Itemid=216

52. World Bank Data, https://data.worldbank.org/country/tajikistan

53. World Population Prospects, 2017 Revison. Volume I: Comprehensive Tables, Department of Economic and Social Affairs Population Division, United Nations, New York, 2017. 